\title{
Kunst uden krop
}

\section{En læsning af Don DeLillos Kropskunstneren}

\author{
This is not history. This is precisely \\ the opposite of history.
}

Don DeLillo, The Names

Don DeLillo er kendt for at skrive romaner der - med hans egen formulering - er »fiktion badet i historie«: sovjetiske atomprøvesprængninger, Kennedymordet, gidseltagningerne i Beirut, Moon-sekten, ayatollah Khomeinis begravelse, fodboldkatastrofen i Sheffield, og meget mere. På den baggrund er DeLillos seneste bog, Kropskunstneren (The Body Artist) fra 2001, noget af en overraskelse. Den lille roman på 124 små sider handler om et ægtepar »kropskunstneren« Lauren Hartke og filminstruktøren Rey Robles - der efter brylluppet har trukket sig tilbage til et ensomt beliggende hus på østkysten. Et kapitel inde i romanen tager manden uden videre bilen ind til ekskonen og skyder sig. Efter begravelsen vender Lauren tilbage til det øde hus hvor hun finder en efter alt at dømme retarderet mand som taler et besynderligt usammenhængende og meningsløst sprog, og som hun navngiver mr. Tuttle. Efter et stykke tid forsvinder han også. Den samtidshistorie som DeLillos foregående romaner tager bad i, er nærmest demonstrativt fraværende i Kropskunstneren. Eller rettere sagt: historien er højst til stede som antydning, i form af Reys traumatiske europæiske fortid og i form af det store, lejede hus der er fuldt af gamle møbler og beskrives som et »relikt« fra tidligere tider. $^{1}$

Ved udgivelsen af Kropskunstneren hæftede de fleste anmeldere sig ved kontrasten til den forrige bog fra 1997, den virtuose og ambitiøse romankrønike om den kolde krigs Amerika Underverden (Underworld). En

1. Don DeLillo: Kropskunstneren, København 2001, p. 13. Originaltekst: The Body Artist, New York 2001. Jeg citerer løbende i teksten fra den danske udgave, der herefter forkortes $K$. Hvor det har været nødvendigt for at tydeliggøre en pointe, har jeg dog ændret i den danske oversættelse 
anmelder beskrev forskellen som et skift fra Den Guddommelige Komedie til haiku; ${ }^{2}$ en anden opfattede den nye roman som DeLillos »selvbevidste rebooting « af sit forfatterskab. ${ }^{3}$ I computersprog er en "re-booting " som bekendt en betegnelse for den nedlukning og genopstart som finder sted når man trykker på tasterne ctrl-alt-del: der skulle altså være tale om en radikal kursændring i DeLillos forfatterskab.

Mit ærinde i det følgende er det ret beskedne at præsentere en mere omstændelig læsning af DeLillos seneste roman. En sådan læsning vil afdække ikke bare kontrasten mellem Kropskunstneren og det forudgående forfatterskab, men også kontinuiteten. I sin seneste bog har DeLillo ikke ændret litterær kurs, mener jeg; han har snarere givet sig tid til at tænke over den kurs som de tidligere romaner har holdt i farvandet mellem fiktion og samtidshistorie. For at skifte til computermetaforikken kan man sige at romanen ikke er DeLillos »re-booting« af sit forfatterskab; den er snarere hans refleksion over det foregående forfatterskabs styresystem.

\section{Edderkoppens verden}

Romanen starter med en edderkop i dens spind: "Tiden ser ud til at gå. Verden sker, folder sig ud i øjeblikke, og du standser op for at se på en edderkop presset $\bmod$ sit spind« $(K$, p. 5$)$. Ligesom vinden går igennem edderkoppespindet, går tiden gennem verden: "vinden suser i fyrretræerne og verden bliver til, irreversibelt, og edderkoppen rider på det vindblæste net« (ibid.). I slutningen af det efterfølgende kapitel, umiddelbart før den tilbagevendte Lauren finder mr. Tuttle siddende i undertøj i et af husets mange glemte værelser, bliver edderkoppespindet nævnt igen. Lauren har hørt en underlig lyd fra husets 1. sal, og på vej derop kigger hun ud af vinduet og ser ikke en edderkop der sidder trygt i sit spind, men - som en slags forvarsel for mr. Tuttle - et blad der drejer frit i luften:

"Hun så et hvirvlende [twirling] blad lige uden for vinduet. Det var et lille ravgult blad som hvirvlede rundt i luften under en gren der strakte sig hen over taget. Der var ikke noget tegn på et larvespind som bladet kunne hænge fast i, eller et hår fra en fugls redebygningsmateriale. Kun bladet der drejede rundt, frit svævende i luften« $(K$, p. 42$)$

2. John Leonard, in New York Review of Books, 22.2. 2001.

3. Tim Adams, in The Observer, 11.2. 2001. 
Hele romanen er spændt ud mellem edderkoppen og bladet: man kan sidde sikkert $\mathrm{i}$ edderkoppespindets tidsgennemblæste verden, eller man kan svæve frit og drejende $\mathrm{i}$ det tomme rum, løsrevet fra alverdens spind og fuglereder. Allerede romanens to første sætninger formulerer denne modsætning i det diskrete, men foruroligende sammenstød mellem at gå og at stoppe: »Time seems to pass ... and you stop«. Tiden går og folder en verden ud, men mennesket kan standse og se verden udefra, som når man betragter edderkoppen i dens spind.

I resten af første kapitel spiser Lauren og Rey morgenmad i huset, den dag hvor Rey begår selvmord. Her folder tiden sig ind i en verden af ristet brød, morgenradio og mysli, og med den udenforstående betragters omhyggelige blik beskrives to mennesker der bevæger sig omkring i deres spind af ubevidste morgenrutiner og søvndrukne samtaler. Men også i denne rutinemæssige verden kan man finde spor af en anderledes fritsvævende tilstand. Rey bruger det meste af morgenen på at have glemt hvad han ville sige, men Lauren insisterer:

"») Fortæl mig det alligevel.«

»Det er for tidligt. Det er anstrengende. Det er kedeligt.«

»Du snakker udenom. Fortæl mig det, «sagde hun.

Hun tog en mundfuld mysli og læste i avisen.

"Det er anstrengende. Det er ligesom hvad er det. Det er ligesom at flytte en klippeblok.»

"Du snakker udenom.»

»Her, « sagde han.

"Du sagde huset. Intet om huset er kedeligt. Jeg kan godt lide huset.»

»Du kan lide alting. Du elsker alting. Du er mit lykkelige hjem. Her, « sagde han« $(K$, p.17).

Efter det sidste »her« rækker han hende en figen som han har smurt ud på et stykke ristet brød, måske for at lukke munden på hende. Men i originalteksten refererer hans »her « ikke bare til figenmaden: "You're sitting there talking', 'Here,' he said." Rey er alt for søvnig til at rette Lauren, men det lyder som om han gør: jeg sidder ikke der og taler, jeg sidder her. De to stedord sætter navn på de to tilstande som romanen er spændt ud imellem: at være her er at sidde i edderkoppespindets »lykkelige hjem«; at være der er på en eller anden måde at svæve hjemløst omkring uden for verden.

De to stedord dukker op et par sider senere hvor Lauren sidder og læser i en gammel søndagsavis: „Hun læste og faldt i tanker. Hun var her og der» («she read and drifted. She was here and there«, $K$, p. 24). Hun er der fordi hun befinder sig i »tryksværtens mærkeligt fastholdte virkelighed«; hun er 
her fordi hun trods alt stadig er en søvnig krop der sidder i et køkken. I læsningens der fører man ustyrlige samtaler med mennesker på den anden side af jorden: „til du bliver klar over at du gør det, og så holder du op, ser hvad der er foran dig i det øjeblik, for eksempel et halvt glas juice i din mands hånd $\ll(K, \mathrm{p} .19)$.

I et af Laurens første forsøg på at forstå mr. Tuttle dukker stedordene her og der op igen: "Måske oplever denne mand en anden form for virkelighed hvor han er her og der, før og efter, og han bevæger sig rystende fra det ene til det andet, i en tilstand af sammenbrud« $(K$, p. 70$)$. Som en slags begyndelse kan man altså beskrive mr. Tuttles som en radikalisering af den læsendes tilstand: han er her ligesom den læsendes krop, men han driver samtidig omkring udenfor i et der. Som mr. Tuttle siger om sig selv, er han "her og hvor» («here and where«, $K$, p. 82).

I slutningen af romanen får vi at vide at Lauren har taget hovedfag på universitetet i filosofi, og når man læser hendes tanker om mr. Tuttle, er der meget der tyder på at hun har fulgt et kursus i Martin Heideggers filosofi. I hvert fald er hun optaget af hvordan verdens her- hos Heidegger tilværens $D a$ - er noget der opstår når tiden går på en særlig, ordnet måde. »Du er skabt af tid« $(K$, p. 102); »tiden folder sig ud i værens fuger [into the seams of being]. Den passerer igennem dig, skaber og former« $(K$, p. 111); tiden eksisterer $» \mathbf{i}$ en beroligende rækkefølge, gå, strømme, finde sted - verden sker [the world happens], det må den gøre, vi føler det - med navne og datoer og sondringer« $(K$, p. 85). I første kapitels morgenmadsscene kan man se hvordan de sondringer der skaber en meningsfuld verden, blandt andet kan være ejendomsforhold: »Det var hans kaffe og hans kop«; »det var hans ristede brød, det var hendes vejr«; »det var hendes avis. Telefonen var hans, bortset fra når hun ringede til vejret«, osv.

At være der er at befinde sig uden for dette spind af menneskelig mening, eller formuleret med Heidegger: i »das Unzuhause «. ${ }^{4}$ Lauren føler at mr. Tuttle »levede et sted i mørket, og det er koldere og mere vinteragtigt der [it is wintrier there]« $(K$, p. 111$)$. En af romanens vigtige figurer for dette uhjemme er det der findes uden for husets fire vægge - ikke mindst fuglene der sidder på foderbrætterne og læser »et budskab i en eller anden begivenhed uden for det synlige spektrum« $(K$, p. 58). En anden uhjemlighedsfigur er internettet. Da Lauren er vendt tilbage til huset, gør hun det til en vane hver dag at gå ind på nettet og betragte et webcam der viser en direkte videoptagelse i real time fra en tosporet indkørselsvej til den finske provinsby Kotka. ${ }^{5}$

4. Martin Heidegger: Sein und Zeit, Tübingen 1986 (org. 1927), p. 189.

5. Et webcam af denne type - der dog viser still-billeder - kan ses på det finske vejvæsens hjemmeside: http://www.tiehallinto.fi/alk/english/frames/kelikamerat-frame.html. 
Det er bedst i de døde perioder, uden særlig mange biler, kommer hun frem til, for da viser computerskærmen et der i ren form: et stykke realitet som ikke er indspundet i meningsfuld verden, »et sted ribbet for alt andet end en vej der nærmer sig og fjerner sig« $(K$, p. 40). Computerskærmens display viser tiden der går i Finland »med en sær og hul insisteren, sekunderne der nærmer sig minuttet, minutterne der kravler frem mod timen. "Det er denne form for tid som mr. Tuttle befinder sig i: en tid som ikke lægger sig pænt til rette $\mathrm{i} »$ begivenhedernes solkyssede kronologi« $(K$, p. 92), og som derfor ikke skaber og former en verden, men bare tikker digitalt af sted, umenneskeligt og »ansigtsløst».

\section{Fignen}

Et par sider før Rey rækker Lauren det ristede brød, bliver vi fortalt hvordan han tilbereder det: »Han bed stilken af og smed den over mod vasken. Så flækkede han fignen med tommelfingerneglen og tog skeen ud af hånden på hende og slikkede den ren og brugte den til at grave en portion bordeauxfarvet kød ud af den gabende figenskræl« $(K$, p. 14). Det ensomme par i haven deler en frugt, og bagefter må Rey visselig dø. Syndefaldsmetaforikken understreges ikke bare af forbindelsen mellem figen og figenblad, men også af passagens umisforståelige seksuelle konnotationer. Kort efter er det Lauren der er den aktive: hun tog fignen fra hans tallerken »og stak en finger ned i den og gravede efter frugtkød,« og bagefter slikkede hun fingeren "på sin figendyppende hånd« $(K$, p. 24$)$.

Efter at have taget en bid af Reys figenmad, vender Lauren tilbage til sin mysli: »Hun tog en mundfuld mysli og glemte at smage på den. Hun gik glip af smagen et sted mellem det tidspunkt hvor hun puttede maden i munden og det beklagelige øjeblik hvor hun slugte den« (K, p. 19). Syndefaldets bid af æblet - eller af myslien - er altså forbundet med glemsel. Ikke en eller anden heideggersk Værensglemsel, men snarere en slags søvndrukken uopmærksomhed over for tingenes smag. Hele morgenmadskapitlet kan bedst beskrives som en detaljeret protokol over den slags søvndrukne forglemmelser: han ville sige noget, men bliver ved med at glemme hvad det var; hun glemmer som regel at høre efter når han endelig siger noget; han har glemt at hun ikke drikker juice; hun rejser sig fra bordet, men har glemt hvad hun skulle hente; han glemmer at han har slukket for radioen og tænder den igen; hun venter på radioens vejrmelding, men glemmer at høre efter når den endelig kommer - osv.

I The Names, DeLillos roman fra 1982, bliver helvede defineret som "mangel på opmærksomhed «. ${ }^{6}$ Det er Rey og Laurens konstitutionelle uop- 
mærksomhed der forvandler deres paradisiske have til et helvede hvor øjeblikkene sluges rutinemæssigt uden at man når at hæfte sig ved deres flygtige smag. Det edderkoppespind af vaner og rutiner der skaber det hjemlige her, åbner altså ikke bare en meningsfuld og hjemlig verden; det tildækker også tingenes virkelighed som et slør eller som et figenblad.

Når Lauren kigger på sit webcam, forestiller hun sig »at nogen måske onanerede til dette, til synet af en bil på vej til Kotka midt om natten.» Umiddelbart kan det være svært at se masturbationspotentialet i en indfaldsvej til en finsk provinsby, men Laurens idé skal formentlig forstås på baggrund af syndefaldstematikken: det ophidsende ved computerbillederne er virkelighedens nøgne realitet; vejen i Kotka er resultatet af en ontologisk striptease, den er »a place stripped of everything «. Hvor morgenmadskapitlet viser en verden der er tildækket af vanens figenblade, viser webcam'et den skamløst blottede virkelighed. Og det er denne før-syndefaldsverden som Lauren oplever glimt af i sit samliv med mr. Tuttle: »der var noget hudløst [raw] ved øjeblikket, som et åbent sår. Det blotlagde ting for hende som lå uden for hendes erfaring, men samtidig på en eller anden måde fortvivlende centralt« $(K$, p. 68).

I den omhyggelige beskrivelse af fignen på toastbrødet fremhæves dens »kød « og dens »blodsmøragtige hvirvler«. ${ }^{7}$ Kødet er i det hele taget en gennemgående figur i beskrivelsen af Laurens og Reys forhold, og også denne gang spiller de kristne konnotationer en iøjnefaldende rolle: der alluderes både til dogmet om inkarnationen (at ånden blev kød) og til dogmet om transsubstantiationen (at dette kød forvandler sig til brød og vin i nadveren). Når Rey og Lauren deler en halvspist figenmad, bekræfter de deres fællesskab ligesom menigheden i den kristne nadver. Og samtidig inkarnerer de deres samtale ved at supplere ordene med kropsbevægelser: „Hun bøjede sig forover, han rakte brødet frem« $(K$, p.14). I en række flashbacks beskrives ægteparrets samtaler som inkarnationens blanding af ånd og kød, af lingvistisk og erotisk kommunikation. Der var blandt andet en vigtig "nat med omtumlede følelser, vage strømme af sex, tilståelse og let søvn, [...] og så døsig sex igen« $(K$, p. 67). Når et par blander bekendelser og døsig sex i den rette dosering, bekræfter de deres fællesskab: to mennesker går "gennem hinanden, let og luftigt som skumsprøjt«. Et sted mindes Lauren »øjeblikke sammen med Rey, ikke direkte øjeblikke, men tider, eller øjeblikke der flød ind i sammensat tid, en erotik af at se og røre« (det lyder bedre på engelsk: "an erotics of see and touch«, $K$, p. 51). Det er ikke mindst denne inkarne-

6. Don Delillo: The Names, p. 295.

7. Frugtkødet beskrives også som »claret« («bordeauxfarvet«), og det er ifølge Oxford English Dictionary ikke bare et ord for vinens røde farve, men også 1600-tals slang for blod. 
rende erotik der får tiden til at opføre sig som en sammensat, skabende og formende tid. Den verden som Lauren og Rey bevæger sig omkring i, deres fælles her, er altså ikke mindst skabt ved hjælp af deres gestiske og seksuelle inkarnation af sproget.

Hovedpersonen i The Names - DeLillos grundigste undersøgelse af sproget - er en "risikoanalytiker« der bor i Athen, men han er ikke særlig god til græsk, og set gennem hans lingvistisk fremmedgjorte blik får vi et billede af hvordan det inkarnerede sprog fungerer:

"People everywhere are absorbed in conversation. Seated under trees, under striped canopies in the squares, they bend together over food and drink, their voices darkly raveled in Oriental laments that flow from radios in basements and back kitchens. Conversation is life, language is the deepest being. We see the patterns repeat, the gestures drive the words. It is the sound and picture of humans communicating. It is talk as definition of itself. Talk. Voices out of doorways and open windows, voices on the stuccoed-brick balconies, a driver taking both hands off the wheel to gesture as he speaks. Every conversation is a shared narrative, a thing that surges forward, too dense to allow space for the unspoken, the sterile. The talk is unconditional, the participants drawn in completely. $\|^{8}$

Ligesom Lauren og Rey læner sig ind mod hinanden over figenmaden, forenes grækerne over mad og drikke i en slags evigt kværnende nadver. Dette sprog er i bogstaveligste forstand inkarneret: det har sit grundlag og sin drivkraft i de talendes kropslige gestus. Det inkarnerede sprog er absolut fordi det først og fremmest fejrer sig selv og de talendes sociale fælleskab, og kun i anden omgang bliver brugt til at sige noget om verden. Men det er også absolut i betydningen enerådende: sproget er for "tæt " til at give mulighed for at være opmærksom på den uformulerede virkelighed - Kotka, for eksempel - der findes uden for det athenske fællesskab.

Mr. Tuttle deltager ikke i det kropslige og gestiske fællesskab. Når Lauren læner sig ind mod ham, læner han sig ikke ind imod hende ( $K$, p. 84). På et tidspunkt sidder mr. Tuttle nøgen i badekarret, da Lauren kommer brasende; alligevel undlader han at dreje hovedet imod hende eller med nogen anden gestus vise at han ved hun er der $(K$, p. 74$)$. Et par sider tidligere tænker Lauren sig frem til at han mangler den gestikulation og intonation der normalt findes uden om den lingvistiske kommunikation (han mangler »de ting en mand der taler hollandsk kunne have til fælles med en mand der

8. DeLillo, op. cit., p. 52 . 
taler kinesisk«). På den baggrund kan Lauren beskrive ham som den diametrale modsætning til den lykkeligt gestikulerende græker:

"Der er en kode i den enkleste samtale som fortæller de talende hvad der foregår uden for det nøgne lydbillede. Den manglede når de talte sammen. Der var en manglende rytme [beat]. Det var svært for hende at finde tempoet. Det eneste de havde, var løsrevne ord. Hun mistede forbindelsen med ham, mistede sommetider interessen, kunne ikke placere rytmiske intervaller eller stikord eller bare mumlen og brummen, de hørlige pauser som driver en bemærkning frem. Hans ansigt viste ingen reaktioner på ting hun sagde, og det bragte hende ud af balance« $(K, \mathrm{p}$. 71).

Når sproget ikke bliver drevet frem af gestikkens beat, bliver den enkelte sætning til løsrevne ord, til en »klynge af ord« $(K$, p. 5l), og mellem de enkelte ord åbner der sig bundløse afgrunde af meningsløshed.

Romanens diskussion af inkarnationen handler ikke kun om forholdet mellem ord og gestus hos det enkelte menneske, men også om hvordan et menneske kan overtage udtryk fra andre. Mens der spises morgenmad, skal Lauren på et tidspunkt hente mælken i køleskabet:

"Hver gang hun måtte bøje sig for at nå ind til de nederste og inderste dele af køleskabet, udstødte hun en stønnen, men ikke helt hver gang, der mindede om en livsklage. Hun var for veltrænet og smidig til at føle nogen anstrengelse og efterlignede [echoing] blot Rey, identificerede sig med ham, stønnede hans stønnen, men på en måde der var så umærkelig og dyb at det også var hendes ubehag« $(K$, p. 7$)$.

Den sidste sætning lyder på engelsk: »in a manner so seamless and deep it was her discomfort too«. Det der er umærkeligt, eller »uden syninger«, er altså den tilegnelse der gør at Laurens ekko af Reys stønnen også bliver hendes egen stønnen. Laurens imitation er med andre ord en form for inkarnation: udtrykket for livsklage er Reys, men Lauren gør det til sit eget kød ved at lade det vokse sammen med sine egne kropslige vaner. En af de mest påfaldende ting ved mr. Tuttle er hans usædvanlige evne til at imitere andre mennesker, ikke mindst den afdøde Reys sprog og gestus. I modsætning til Lauren er mr. Tuttle imidlertid ikke i stand til at indoptage Reys udtryk i sin egen krop; han udstiller snarere syningen mellem det fremmede udtryk og den egne krop. Han har med andre ord renset imitationen for inkarnation, og det er det der gør hans efterligninger lige så gode som en båndoptagers. 
Endelig tager inkarnationen også form som et erkendelsesteoretisk problem. I sine forsøg på at forstå mr. Tuttles verdensopfattelse bliver Lauren nødt til trække på sin filosofiuddannelse og tænke over hvordan mennesker normalt opfatter verden. Det, der interesserer hende, er hvordan "sproget gennemskærer vores opfattelser af tid og rum« $(K$, p. 110). »Det er meningen at øjet skal forme og bearbejde og male. Det fortæller os en historie vi gerne vil tro« $(K$, p. 89$)$; at se noget er »at skrive det som en linie i et stykke litteratur« $(K$, p. 101). Ifølge denne betragtning er sproget ikke blot inkarneret i gestik og intonation, men også i sanseorganerne for så vidt de er gennemtrukket af sproglig mening. Hvis perceptionen bruger sproget til at male verden med, er der imidlertid også mulighed for at den maler forkert, og det er denne mulighed som ligger til grund for romanens mange sansebedrag: man ser et dødt egern i indkørslen, men ved nærmere eftersyn viser det sig at være en strimmel krøllet hessian ( $K$, p. 121$)$; man hører hvordan en papirclip rammer gulvet og husker svagt hvordan den gled af papiret, men når man bukker sig ned, opdager man at man slet ikke har tabt nogen clip ( $K$, p. 99); man ser fra bilen en mand sidde på sin veranda, "skilt og drikfældig, følelsesmæssigt fjern fra sine børn, sine sønner", men idet bilen suser forbi, opdager man at det bare var en dåse maling på et bræt $(K$, p. 77$)$. Normalt har ånden - forstået som sproglige og kulturelle koder - inkarneret sig solidt i den kropslige sansning; men når man bliver klar over et sansebedrag, får man øje på afstanden mellem på den ene side de velkendte, kulturskabte billeder af verden - som ikke mindst Hollywood har leveret - og på den anden side virkeligheden selv: "Når telefonen ringede, så hun ikke på den sådan som de gør i filmene. I virkeligheden ser folk ikke på telefoner der ringer« $(K$, p. 34$)$. Mr. Tuttle er fremmed ved det skæringspunkt hvor sprog og perception griber ind i hinanden $(K$, p. 110), og han ser derfor ikke verden "på den sædvanlige fortolkende måde« $(K$, p. 106). I stedet oplever han virkeligheden ufortolket, ufiktionaliseret og uden »beskyttende overflade«: han ser »tingenes hylende ansigt, deres nøgenhed, deres ikke-som-om« $(K, \mathrm{p}$. 100).

På de tre nævnte niveauer (som man kunne vælge at kalde hhv. kommunikation, imitation, perception) tvinger mr. Tuttle inkarnationens to sider, ånden og kødet, bort fra hinanden. Resultatet bliver på den ene side et diskarneret sprog og på den anden side - adskilt af en uoverskridelig distance en afspiritualiseret krop. Det diskarnerede sprog minder om den slags syntetiske telefonsvarerstemmer der siger »Ind-tal / ven-ligst / en / be-sked / ef-ter / klar-to-nen« $(K$, p. 73$)$. Og det minder om den katolske kirkes messen hvor ordene "strømmer frem, sanselige og tomme« $(K, \mathrm{p}$. 83). I stedet for at henvise til den verden som kroppen bevæger sig omkring i, peger mr. Tuttles »ujordiske « ${ }^{9}$ og "neutrale« $(K$, p. 73$)$ sprog cirkulært tilbage på sig selv. 
En af hans karakteristiske replikker er: »ordet for måneskin er måneskin« (K, p. 91). Den modsatte side, den afspiritualiserede krop, kan man blandt andet finde hos sovende mennesker:

"I søvne var han ikke mere uerkendelig end alle andre. Se. Den indhyllede krop banker svagt [feeble beat]. Det er det du føler når du ser på den tyste og sårbare krop, næsten hvem som helsts, eller du ligger ved siden af din mand efter at have elsket og indånder varmen fra hans nådesløse drømme og spekulerer på hvem han er« $(K$, p. 58).

I søvnen er selv den mest velkendte krop anonym - eller næsten anonym for den følger ikke længere beat'et i det erotiske og gestiske fællesskab. I stedet vender den sovende sig indad mod den rytme som findes i hjertets metronomiske »feeble beat«. Selv når han er vågen, minder mr. Tuttles krop om den sovendes: hans gestus retter sig ikke efter samtalens koder, men foregår "autonomt, styret af en lov hans krop selv havde udtænkt« ( $K$, p. 94). Det mystiske ved mr. Tuttle er med andre ord at inkarnationens mysterium ikke finder sted, men ånden og kødet følger hver deres autonome love.

\section{Skadens blik}

Som ung studerede DeLillo på det jesuitiske Fordham College i New York, og han har sagt at det var jesuitterne der »lærte ham at blive en mislykket asket. $«^{10}$ Jesuitterne ville formentlig også opfatte den kristne metaforik i Kropskunstneren som mislykket. Syndefald og inkarnation hører som bekendt hjemme i hver sin ende af den kristne forestillingsverden: vi blev syndige fordi Adam spiste af æblet, men til gengæld lod Kristus sig føde som et løfte om forløsning. DeLillo vender den kristne dogmatik på hovedet ved at pakke syndefald, inkarnation og nadver ned i den samme figenmad. I Kropskunstneren er den faldne verden den verden hvor ånden har taget bolig i kødet. Det betyder omvendt at forløsningen må finde sted ved en slags negativ inkarnation: et diskarnationens mysterium.

I The Names opstiller en af hovedpersonerne en teori om litteraturens forsøg på at distancere sig fra det kulturelt formede sprog:

9. Ordet er »unearthly«, The Body Artist, p. 50 (ikke »overnaturlig« som i den danske oversættelse, $K$, p. 53).

10. Robert E. Harris: „A Talk with Don DeLillo«, The New York Times, 10. oktober 1982. 
"In this century the writer has carried on a conversation with madness. We might almost say of the twentieth-century writer that he aspires to madness. Some have made it, of course, and they hold special places in our regard. To a writer, madness is a final distillation of self, a final editing down. It's the drowning out of false voices«. ${ }^{11}$

Senere i denne roman bliver ambitionen om at drukne historiens falske stemmer på meget radikal vis ført ud i livet af en uhyggelig sekt der ser det som sin mission at myrde tilfældige mennesker med de samme initialer som den by hvor mordet finder sted. Ved udelukkende at interessere sig for ordenes bogstaver, og ikke for deres indhold, har sekten konstrueret en sproglig logik »uden mening, uden indhold, uden historiske bånd, uden rituel betydning ${ }^{12}{ }^{12}$ Deres bortdestillering af historisk mening lykkes bedst $\mathrm{i}$ øde bjergområder og ørkener »hvor det er muligt for mennesker at holde op med at lave historie, «forklarer et medlem af sekten: »Vi opfinder en udvej. «" ${ }^{33}$ Også Kropskunstneren kredser om en sådan udvej fra historien. Den findes i Reys selvmord (der ifølge hans forhenværende kone var "hans udvej«, $K$, p. 63). Den findes i Laurens »kropskunst« der går ud på at rense kroppen for kulturens stemmer ved hjælp af hårfjerning, hudslibning, tungerensning, klipning og afblegning. "Det var hendes arbejde at udslette alle sine tidligere former for udseende og fremtræden og blive helt blank, en kropstavle visket ren for enhver fortidig lighed« $(K$, p. 93). Og den findes som nævnt i Laurens omgang med mr. Tuttles særlige form for galskab. I disse samtaler befinder Lauren sig ikke i kultmedlemmernes øde ørken, men i rummets endnu mere radikale historieløshed: hun føler sig "som en person i sort spandex i en science fiction film« $(K$, p. 61). Den litterære destillationsproces der beskrives i The Names, tager altså i Kropskunstneren form som en diskarnationsproces der renser den kropslige erfaring for alle historiens mumlende stemmer. Formuleret med Michel Foucault er den moderne litteratur beslægtet med galskaben fordi de begge desartikulerer det kulturelle sprog og giver et glimt af det »dehors», det »udenfor» der findes hinsides den historisk formede erfaring. ${ }^{14}$

11. DeLillo: The Names, p. 118.

12. DeLillo op. cit., p. 216.

13. Kultmedlemmet befinder sig i Mani-bjergene i det centrale Peloponnes: "This is the strength of the Mani. It does not suggest things to us. No gods, no history. The rest of the Peloponnese is full of associations. The Deep Mani, no. Only what is here. The rocks, the towers. A dead silence. A place where it is possible for men to stop making history. We are inventing a way out, « DeLillo, op. cit., p. 209.

14. Michel Foucault: „La folie, l'absence d'œuvre«, in: Folie et déraison. Histoire de la folie à l'âge classique, Paris 1972. 
Kropskunstneren rummer imidlertid ikke blot denne quasi-religiøse transcendensbevægelse, men også en modsatrettet bevægelse tilbage til verden. Umiddelbart efter at ægteparret har delt figenmaden, lander en blåskade på foderbrættet uden for køkkenvinduet ( $K$, p. 22). Lauren oplever situationen som en epifani, og det der fascinerer hende, er ikke blot at fuglen befinder sig uden for hendes bogomgrænsede verden, men først og fremmest at den derudefra ser tilbage mod hendes verden - på samme måde som betragteren i romanens første scene betragter edderkoppen ride på dens vindblæste net: „Når fugle kigger ind i huse, hvilke umulige verdener ser de så ikke. Tænk. Hvilken afkastning [shedding] af enhver kendelig overflade og proces" $(K$, p. 22$)$. "Shedding« bruger man blandt andet om hunde der fælder, og om slanger der skifter ham: set igennem skadens blik (forestiller Lauren sig) foregår der altså endnu en ontologisk striptease hvor hendes egen verden bliver skrællet for dens vante betydningssammenhænge. Skaden beskrives som en »rederøver og dygtig imitator» - ligesom mr. Tuttle der røver ægteparrets hus og imiterer deres stemmer. Det er da også påfaldende at Lauren hele tiden forsøger at se tilbage mod sin egen verden gennem mr. Tuttles blik. Hun spørger »Hvad ser du?«(K, p. 46); hun undrer sig over hvad ting betyder for ham ( $K$, p. 47$)$; hun spekulerer på »hvad han så, eller ikke så, eller så så anderledes at hun overhovedet ikke kunne fremmane dets omrids« $(K$, p. 53). På et tidspunkt tager hun ham endda med til noget så velkendt som et supermarked »i det forfængelige håb at se ting gennem hans øjne, verden i sin geometriske form, mønstret og stablet, og de lange gange med varer og kunderne i steppende trance og hvad der ellers måtte påkalde sig hans blik som man selv har glemt hvordan man ser« $(K$, p. 70$)$.

Det er dette håb om at se verden gennem mr. Tuttles øjne og sprog der ligger til grund for romanens poetik. Som eksempel kan man tage den fortvivlede »kamp« som mr. Tuttle må udkæmpe for at få ordene til at give mening: »fordi jeg er her og hvor. $O g$ jeg vil rejse eller ikke eller aldrig« $(K, \mathrm{p}$. 83). Den slags kæder af fortvivlede disjunktioner og selvkorrektioner genfinder man i rigt mål hos romanens fortællerstemme. I morgenmadskapitlet hedder det eksempelvis at Lauren »havde en form for hyper-beredskab, eller hovedløst, eller hidsigt, og Rey sagde altid, eller han havde sagt en enkelt gang«, osv. (K, p. 16). For at kunne se det som vi har glemt hvordan man ser, må fortælleren mime mr. Tuttles diskarnerede sprog; først på den måde bliver det muligt at se en alt for velkendt verden udefra gennem skadens blik. Lauren forestiller sig vel at mærke ikke at mr. Tuttle vil opleve supermarkedet som et kaos af former og farver; hun mener derimod at han er i stand til at få øje på dets "geometriske form, mønstret og stablet«. Tilsvarende opfatter hun ikke hans messende sprog som en tilfældig ophobning af desartikulerede ord, men som en særegen skønhed der følger sin egen cir- 
kulære og klanglige logik. Når romanen forsøger at beskrive den alt for velkendte verden gennem mr. Tuttles øjne, er det altså ikke for at nærme sig et formløst kaos, men snarere for at få øje på en orden der følger sine egne autonome principper: en verden der er mønstret og stablet anderledes.

\section{Litteraturens forløsning}

I essayet »The Power of History«, som blev trykt i New York Times i forbindelse med udgivelsen af Underverden i 1997, beskriver DeLillo samtidshistorien som en kur mod romanforfatterens hypertrofiske inderlighed. „Den lidenskabelige beherskelse af dokumentarisk materiale er en forfriskende kur mod den selvkredsen og den nådesløse inderlighed som en lang roman kan udsætte en forfatter for. $\|^{15}$ Men det er vel at mærke ikke kun historien der har magt til at redde litteraturen fra at gå i spin om sig selv, det er også omvendt litteraturen der kan redde historien. Lidt senere i det korte essay skriver DeLillo:

"Sproget lever i alt hvad det rører ved, og det kan være forløsningens agent, det kan være den ting der på paradoksal vis forløser os fra historiens flade, tynde, tætte og uopholdelige mekanismer, dens arrangementer af voldsomme sider, og den ting der gør det muligt for os at finde en uindskrænket andethed, en fri drejen bort fra tid og sted og skæbne«.

Når det litterære sprog kan give en bortdrejning (»a free veer«) fra den skæbneagtigt tyngende historiske situation, er det fordi litteraturen i sit inderste væsen er en selvkredsende bortvendthed der kan minde om religiøse erfaringer: "på sit basale niveau er fiktion en form for religiøs fanatisme, med elementer af besættelse, overtro og ærefrygt«. Ifølge DeLillos historieessay vender litteraturen altså både forfriskende ud mod historien og fanatisk ind mod sig selv. Det kunne lyde som en selvmodsigelse, men handler nok snarere om to forskellige bevægelser i det litterære arbejde. Når romanforfatterens eksempelvis bruger en historisk figur, drejer han ifølge DeLillo figuren ud af dens kontekst i en drejende bevægelse (denne gang »a swerve«): »han vil foranstalte en fradrejning fra de sædvanlige arrangementer der binder den historiske figur til hvad der er blevet rapporteret, sagt, bekræftet eller højtideligt messet.«Romanforfatteren skal imidlertid ikke bare dekontekstualisere den historiske figur, han skal også rekontekstualisere den; DeLillo kalder denne modsatrettede bevægelse for en rematerialisering og en rekon-

15. Don DeLillo: »The Power of History«, in New York Times, 7.9. 1997. 
figurering: »i sidste ende vil forfatteren rekonfigurere ting sådan som hans egen historie kræver det.«

I forbindelse med udgivelsen af Libra i 1988 gav DeLillo et af sine sjældne interviews, og her formulerede han den samme idé: "fiktion redder historien fra dens forvirringer [...] Romanen befinder sig inden for historien, men kan også operere uden for historien - den kan korrigere, opklare, og, måske som det vigtigste, finde rytmer og symmetrier som vi ganske enkelt ikke møder andre steder. $\aleph^{16}$ Romanens sprog opererer altså i en autonom sfære uden for historiens former, men det er netop denne distance der gør det muligt at afdække rytmer og symmetrier i det historiske materiale.

Som vi har set, finder man en tilsvarende dobbeltbevægelse af defigurering og rekonfigurering i Kropskunstneren. Den defigurerende bevægelse er det "free veer« eller "swerve« der afkaster de givne historiske former i en drejende transcendensbevægelse: det hvirvlende, fritsvævende blad uden for vinduet; kroppen der »hævede sig og snurrede rundt« i Laurens kropsøvelser $(K$, p. 81); mr. Tuttles ord som »vandrede og snurrede« $(K$, p. 66). Formuleret med historieessayet er mr. Tuttles tomt messende sprog et eksempel på en »uindskrænket andethed«: det er »uden forbindelse med indkomstniveau eller verbaltider eller hvad hans forældre ser i fjernsynet« $(K$, p. 53$)$. Det er dette diskarnerede sprog som Lauren oplever som forløsende: »hun følte en lettelse i sin krop der trak hende ud af besværlige tanker og ind i noget næsten ustyrligt« (K, p. 82). At høre mr. Tuttles religiøst messende stemme »leder tanken hen på en energisk udfrielse, et middel til flugt fra jegets bogomsluttede begrænsninger« $(K$, p. 51$)$. Det var de samme to ord "release« og »escape« - som DeLillo brugte om det litterære sprog i historieessayet.

Den rekonfigurerende bevægelse består i romanens forsøg på at kaste et blik tilbage på den velkendte verden gennem skadens og mr. Tuttles fremmede øjne. Hvis litteraturens sprog kan forløse verden, er det fordi det måske kan gøre det muligt at se den faldne verden på ny i Paradisets oprindelige lys. Denne poetologiske ambition spejler sig eksempelvis i Laurens insisteren på at overtage Adams navngivningsopgave. Hun lader nemlig ikke bare mr. Tuttles diskarnerede sprog dreje hende ud af hendes velkendte verden; hun forsøger også konsekvent at genoprette den kropslige forbindelse mellem ordene og tingene ved at pege på tingene og sige deres navn. ${ }^{17} \mathrm{På} \mathrm{et}$ tidspunkt insisterer hun endda på at læse højt fra et fysiologisk værk om menneskefostret, som om den pegende gestus kunne få verden til at begynde

16. Anthony DeCurtis: "'An Outsider in This Society’, An Interview with Don DeLillo«; genoptrykt i Lentricchia: Introducing Don DeLillo, Durham 1991, p. 56. 
forfra: "Hendes hånd svævede stadig i luften hvor den udmålte fosteret for ham, med tommel og pegefinger til at angive længden« $(K$, p. 66).

$\mathrm{Nu}$ om dage hvor kunst med en vis automatisme bliver tænkt som negation og destruktion af den kulturelt givne mening, klinger DeLillos formuleringer om litteraturens »forløsning« og "redning« af historien noget umoderne. ${ }^{18}$ Men hvis man ser på hvordan forestillingen om en litterær forløsning bliver gennemarbejdet i Kropskunstneren - og det er netop hvad jeg har forsøgt at gøre i det ovenstående - er det tydeligt at DeLillo ikke har nogen ambitioner om at vende tilbage til den idealistiske æstetiks halvteologiske forestillinger om kunstværkets forsoning af sanseligt og oversanseligt. Han interesserer sig ikke for en transfiguration der løfter den endelige verden op i ideernes sfære, men for en rekonfiguration af verdens materiale. Ifølge DeLillo forløser litteraturen ikke historien ved at pege på en højere og sandere verden, men derimod ved at bruge sin fanatiske verdensbortvendthed til at skabe meningsfulde mønstre og symmetrier i den foreliggende verdens rod: historiens begivenheder, men mønstret og stablet efter litteraturens logik.

17. Lauren peger på sig selv og siger »jeg hedder Lauren« (K, p. 59); hun peger ud i luften og viser at Rey var »så høj« (K, p. 84); hun følger stjernebillederne med fingeren ( $K$, p. 91); hun kortlægger omhyggeligt mr. Tuttles nøgne krop når han ligger i badekarret («det her er armhulen, én og to«, $K$, p. 74).

18. Det er også påfaldende at begreberne om forløsning og redning ikke spiller nogen rolle $\mathrm{i}$ DeLillo-forskningen, hvor man først og fremmest vil se DeLillo som en kritisk diagnostiker af den postmoderne verden. I en aktuel artikel tager Skip Willman udgangspunkt i citatet om litteraturens evne til at finde mønstre og symmetrier i en kontingent verden. Men fordi hans æstetikteoretiske begrebsapparat er hentet hos Adorno, må han fejllæse citatet som om det udelukkende handlede om litteraturens negerende, og ikke dens rekonfigurerende kraft: »In the case of Libra, DeLillo assembles and organizes the historical materials of The Warren Commission Report in conjunction with several conspiracy theories of the assassination. Libra, however, does not vindicate either narrative of the JFK assassination, but rather negates each plot by revealing its moment of untruth, the blind spot that enables each narrative to restore meaning and/or stability to social reality following this traumatic event. "Skip Willman: »Art after Dealey Plaza: DeLillo's Libra«, in Modern Fiction Studies 45.3. (1999), p. 623. 